\title{
EDITORIAL
}

\section{VIENTOS DE PANDEMIA... PELUSAS DEBAJO DE LAS ALFOMBRAS}

\author{
J. Javier Soldevilla Agreda \\ Director GNEAUPP
}

En estos tiempos convulsos que la pandemia de COVID-19 está taladrando en todos los horizontes sanitarios, económicos, personales y sociales, han sido muchos, para cada uno de nosotros, rincones que quizá habíamos ayudado a encerrar, por poco relevantes y molestos debajo de tapices profesionales, frenesí científico, credo en personas, fe en modelos solo erigidos en cartón piedra, personas cuya reputación ideológicamente y carisma no pasaron los suficientes filtros que han de exigirse, valores humanos en relación con los otros que parecían no tener género de duda ni de sospecha, cimientos invulnerables en nuestro devenir como enfermeros gerontológicos y como cuidadores de pacientes con heridas, y permitidme una vez desde esta tribuna sincerarme, seguro sin acierto, y enumerar un correlato de nuevas situaciones que por quizá encontrarse ocultas debajo de esas tupidas alfombras del "desarrollo" no hemos tenido deseo o tiempo de analizar. No pretendo hacer un vasto detalle de todo lo que a buen seguro hemos sentido en este semestre, pero desde mis ojos de cuidador, de crédulo ciudadano, seguro he barrido también bajo el lienzo. No quiero hacer listas demoniacas de errores, sino de impresiones, de circunstancias de variado calado que creo pueden servirnos para dar una vuelta y revisar en qué hemos fallado y qué podemos proponer, en qué emprender para que un viento de pandemia como el que nos asola no rompa ni haga irreversible un futuro. Disculpad por focalizarlo en los protagonistas que ilustran estas páginas desde hace más de un cuarto de siglo.

Un telegrama para la reflexión, un primer espacio de visible desolación lo presenta en un extremo de esa alfombra que "todo lo cumbre", la clase, el carisma y la dignidad de algunos responsables políticos-sanitarios que al inicio de un ańo 2020 vuelto hacia la Enfermería como disciplina estelar, exhortaban la necesaria era del cuidado para la ciudadanía, un vuelco a la necesaria presencia de profesionales expertos en ello y el nacimiento de puestos decisivos ocupados por enfermeras que abría ilusión para reformas enquistadas en modelos tradicionales, tanto en la atención primaria como especializada. Pero ¿qué ha pasado con esta situación? En muchos lugares y en poco tiempo, aquellos luchadores en aras de este cambio, en circunstancias de crisis, con todo el tesón, buen hacer, han sido relevados o los cuidados eclipsados por un mandato covidiano de salva vidas, hospitalcentrismo, medicalización y... dejando al descubierto al tiempo lo importante que para esos responsables es la imagen, su ideología, su poder y anulando aquellas demagógicas convicciones que nacieron con el año 2020, dejando de lado el peso del cuidado en salud y enfermedad.

Hay un enorme espacio debajo de esa alfombra, aspiro voladora, que con toda la crueldad ha sobrepasado sus límites e inundado una gran parte de territorio habitable. Son los mayores, son las residencias de mayores, también sus domicilios, y junto a ellos las enfermeras gerontológicas. ¿Qué hemos hecho?, ¿cómo con impunidad en numerosas ocasiones hemos decidido en vida y muerte?, ¿cómo son esos edificios alicatados donde residen millares de nuestros veteranos?, donde solo es negocio y fachada las condiciones en las que viven, detrás de visillos curiosos a la vista desde el exterior, pero con un enorme vacío de posibilidades, de seguir una vida con dignidad, de estar seguros, de no importar a casi nadie. No había ruido, pelusas veladas con muestras de trato inhumano de vez en vez, pero los creíamos insertos en un sistema de protección que ahora ha hecho agua. Dejados, aislados, abandonados. Establecimientos muchos de ellos, la mayoría, sin personal suficiente, sin profesionales de enfermería que pudieran abastecer de cuidados lo cotidiano y dar una oportunidad a enfrentarse a esta locura. Muchas veces hemos aflorado en estas líneas situaciones de mercadeo en el negocio de las residencias, de falta en muchas de ellas (afortunadamente todavía hay muchas otras que no) de valores por una mercancía valiosa y solo jugoso sustento para las arcas de esos emprendedores. Reglamentos bajo la cubierta de viviendas permanentes para un trato adecuado de los mayores, sostenido en ratios raquíticos y equipos profesionales sin cualificación, horas de enfermeras generalistas como si de reponedoras de supermercado se trataran, orientaciones organizativas esquivas o difíciles a la promoción de la salud y ante un enemigo como el manifestado, diezmante. Hemos olvidado la fragilidad negada a muchos de esos mayores, en instituciones o en casa, que no tienen armas de envergadura para luchar en licitud. ¿Cómplices? No lo merecen. No se lo puede permitir una sociedad dícese aventajada y construida en la igualdad y el respeto. Falacias. Tenemos que volver al principio.

No quisiera dejar de ocupar la búsqueda de más "basura” debajo de esta alfombra sin recalar, como objeto de nuestra publicación también, en el hecho de la atención de los pacientes con heridas en estos meses. Si ya de forma aceptada por muchos en el ámbito sanitario, lesiones de segunda en muchos pacientes de tercera, también este tiempo ha dejado al descubierto algunas joyas que será necesario relacionar para actuar enseguida si esa ansiada normalidad, de verdad se acerca: los pacientes heridos en los domicilios con puertas restringidas en los centros de salud y parecen limitadas posibles asistencias dentro. Las unidades de heridas especializadas. Las lesiones de nueva creación, lesiones cutáneas relacionadas con la dependencia en prono, mayúsculas como tiempo atrás no se vislumbraban, lesiones por presión de gran severidad en UCI, en domicilios, quien sabe en residencias. Lesiones cutáneas por el uso de EPI, y sobre todo una montańa también cernida sobre este grupo de cierta dejación.

No quisiera que estas pocas líneas dictadas personalmente por tu vivencia y la información que con el filtro que tratas de imponer recibes a diario, imágenes con y sin sonido de una realidad, que quisiera de corazón poner como meta para encarar un tiempo nuevo donde estos protagonistas, donde las personas a las que nos debemos tengan una oportunidad de alcanzar una atención sanitaria y social justa, accesible, igualitaria, de calidad.

La Ciencia, prioritaria al servicio de la Salud y de la autonomía. El conocimiento científico, motor para la transformación. La conciencia profesional, dignatario de los más débiles.

Tiempo de reflexión desde debajo de la alfombra 